Multidisciplinary Journal - Volume 3, Nomor 2, 2020

Contents list available at Multidisciplinary Journal website

Multidisciplinary Journal

Journal homepage: https://jurnal.unej.ac.id/index.php/multijournal

\title{
Kebiasaan Merokok dan Umur Terhadap Kejadian ISPA Pada Petani Di Kecamatan Ijen Bondowoso
}

\section{Smoking habits and the age of ARI Occurrence in Farmers in Ijen District Bondowoso}

\author{
Aditya Sapta Wardana ${ }^{1}$, Isa Ma'rufi ${ }^{2}$, Ristya Widi E Y ${ }^{3}$

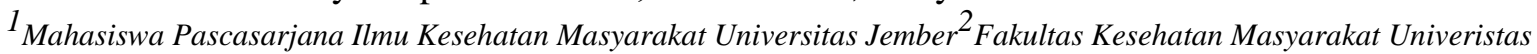 \\ Jember ${ }^{3}$ Fakultas Kedokteran Gigi Univeristas Jember \\ Email: adityasapta3@gmail.com
}

\begin{abstract}
ABSTRAK. Infeksi Saluran Pernapasan Akut (ISPA) merupakan penyakit yang tinggi ditemukan pada petani di wilayah Ijen Bondowoso. Beberapa faktor yang dapat memungkinkan penyebab terjadinya ISPA yaitu faktor individu, perilaku dan lingkungan .Tujuan penelitian ini yaitu menganalisis pengaruh kebiasaan merokok dan umur terhadap kejadian ISPA (Infeksi Saluran Pernapasan Akut). Jenis penelitian adalah observasional analitik dengan desain cross sectional. Data yang digunakan yaitu data primer yang diperoleh pemeriksaan ISPA dan juga kuisioner 101 responden petani. Alat analisis menggunakan SPSS 22.0 Hasil analisis data menunjukkan bahwa: 1) Umur berpengaruh secara signifikan terhadap kejadian ISPA. 2) Kebiasaan merokok berpengaruh positif dan signifikan terhadap kejadian ISPA pada petani.
\end{abstract}

Kata Kunci: Kebiasaan Merokok, Umur,Infeksi Saluran Pernapasan Akut

ABSTRACT. The number of Acute Respiratory Infection (ARI) among farmer showed high in area of Ijen - Bondowoso. There are several risk factors that may contribute of ARI case, such as individual factor, behavior, and environment. This study aims to analyze the correlation between smoking behavior and age toward acute respiratory syndrome among farmer. This was observational analytics, where the study design was cross sectional. The data was primer, where the information was collected from 101 farmer as respondent. This study was analyzed in SPSS 22.0. This study found that: 1) Age is correlated toward ARI case among farmer, and 2) smoking behavior also showed significant toward ARI case among farmer.

Keyword: smoking behavior, age, acute respiratory infection

\section{Pendahuluan}

Infeksi Saluran Pernapasan Akut (ISPA) merupakan penyakit yang disebabkan oleh virus atau bakteri yang biasanya terjadi dalam waktu 14 hari atau juga lebih, dengan gejala umum seperti kesulitan bernapas, batuk, tenggorokan sakit, demam, pilek dan sakit telinga. Penyakit ini menduduki peringkat pertama dari 10 penyakit terbantak di Indonesia, dan juga merupakan salah satu alasan atau penyebab kunjungan pasien di rumah sakit (15\%-30\%) dan Puskesmas (40\%-60\%) (Kemenkes RI 2014) ${ }^{[1]}$.

Ada beberapa faktor yang dapat memungkinkan penyebab terjadinya ISPA yaitu faktor individu, perilaku dan lingkungan. Faktor individu salah satunya yaitu umur. Semakin bertambah umur seseorang maka otot otot pernapasan akan terjadi degenerasi dan diikuti oleh penurunan elastisitas jaringan (Nelson 2014 ${ }^{[2]}$. Pada anak laki - laki dan perempuan di usia 15 hingga 24 tahun memiliki risiko terkena ISPA, dan bagi anak laki - laki risiko tersebut akan menjadi dua kali lebih besar yang mana kebutuhan oksigennya lebih banyak.

Kemudian faktor perilaku salah satunya yaitu kebiasaan merokok. Asap merokok mengandung ribuan zat kimia yang bersifat iritan dan dapat menyebabkan infeksi pada saluran pernapasan serta dapat menimbulkan kanker. Kondisi yang dapat membuat kadar oksigen rendah yaitu jika kita berada di ketinggian, 
digunung, dan ruangan tertutup dipenuhi oleh asap rokok yang menyebabkan perokok mengalami hipoksia kronis (Syam 2012) ${ }^{[3]}$.

Kebiasaan merokok merupkan suatu pola hidup yang secara terus menerus atau berulang yang sulit dihentikan sehingga menjadi kebiasaan yang sangat susah untuk dihentikan. Dampak kualitas udara yang buruk terhadap pernapasan dapat menyebabkan melambatnya pergerkan silia hidung sehingga menghambat proses pembersihan saluran pernapasan akibat adanya iritasi polutan, sehingga merasa kesulitan bernapas. (Mukono 2008) ${ }^{[4]}$. Data dari Puskesmas Ijen, penyakit ISPA selalu menjadi penyakit tertinggi pada laporan bulanan.

Penelitian yang dilakukan pada pekerja pengepakan kertas bekas didapatkan data yaitu sebanyak 67 pekerja merokok dan secara signikan berpengaruh terhadap kejadian ISPA yaitu dngan nilai $p$ value sebesar 0,000. Hasil observasi yang telah dilakukan sebagian pekerja memiliki kebiasaan merokok pada saat bekerja (Pujiani 2017) ${ }^{[5]}$. Penelitian pada Pekerja di Pabrik Asam Fosfat PT. Petrokimia Gresik dihasilkan nilai p value sebesar 0,025 yang diartikan ada hubungan yang bermakna antara kebiasaan merokok pekerja terhadap kejadian ISPA (Sholikhah 2015) ${ }^{[6}$

\section{Metode Penelitian}

Pendekatatan kuantitatif merupakan metode yang digunakan dalam penelitian ini. Observasional analitik merupakan jenis penelitian yang digunakan dalam penelitian ini dengan pendekatan cross sectional. Populasi penelitian yaitu semua petani yang bekerja dan bertempat tinggal di sekitar daerah aliran sungai Kecamatan Ijen yaitu berjumlah 101 orang. Sampel yang digunakan pada yaitu seluruh petani yang berada disekitar daerah aliran sungai Watucapil (total sampling). Proses pengumpulan data dilakukan dengan pemeriksaan, wawancara, dokumentasi dan observasi. Pemeriksaan dilakukan oleh dokter di Puskesmas Ijen. Analisis menggunakan regresi logistik dengan alat SPSS 22.0

\section{Hasil dan Pembahasan}

1. Analisis Univariat

a. Umur dan Kebiasaan Merokok

Tabel 1. Hasil analisis univariat

\begin{tabular}{clll}
\hline Variabel & Kategori & $\mathbf{N}$ & \% \\
\hline \multirow{4}{*}{ Umur } & $36-45$ th & 25 & 24,7 \\
& $46-55$ th & 42 & 41,6 \\
& $>56$ th & 34 & 33,7 \\
& Total & 101 & 100 \\
& Tidak & 47 & 46,5
\end{tabular}

\begin{tabular}{clcc}
$\begin{array}{c}\text { Kebiasaan } \\
\text { Merokok }\end{array}$ & $\begin{array}{l}\text { Merokok } \\
\text { Perokok } \\
\text { Ringan } \\
\text { Total }\end{array}$ & 54 & 53,5 \\
& 101 & 100 \\
\hline
\end{tabular}

Variabel umur menunjukkan bahwa kelompok umur 46-55 tahun (Tabel 1) memiliki persentase yang lebih besar diantara kategori kelompok yang lain dengan $41,6 \%$ atau sebanyak 42 responden, pada variabel kebiasaan merokok diperoleh hasil bahwa jumlah perokok ringan sebanyak 54 orang atau sekitar 53,4\% dibandingkan petani yang tidak merokok.

\section{b. Kejadian ISPA}

Tabel 2. Hasil Pemeriksaan ISPA

\begin{tabular}{clcc}
\hline Variabel & Kategori & N & \% \\
\hline \multirow{3}{*}{ Kejadian Penyakit } & Tidak ISPA & 43 & 42,6 \\
& ISPA & 58 & 57,4 \\
& Total & 101 & 100 \\
\hline
\end{tabular}

Angka kejadian ISPA (Tabel 2) menunjukkan bahwa sebanyak $57,4 \%$ atau 58 orang terkena penyakit ISPA ringan, sedangkan sebanyak $42,6 \%$ atau sejumlah 43 orang tidak terkena ISPA.

2. Analisis Bivariat

Tabel 3. Analisis Statistik

\begin{tabular}{lcc}
\hline \multicolumn{1}{c}{ Variabel } & Chi Square & Sig \\
\hline Umur & 7,141 & 0,028 \\
Kebiasaan Merokok & 27,466 & 0,000 \\
\hline
\end{tabular}

Hasil uji statistik (Tabel 3) didapatkan nilai chi square variabel umur sebesar 7,141 lebih besar dari nilai chi square tabel 3,84 dan p-value sebesar 0,028 lebih kecil dari $\alpha$ (tingkat kesalahan 0,05). Hasil tersebut menunjukkan bahwa umur berpengaruh terhadap kejadian penyakit ISPA petani di Kecamatan Ijen .

Penurunan otot - otot pernapasan dan elastisitas jaringan akan terjadi seiring bertambahnya usia, kemudian pada saat menghirup oksigen kekuatan otot otot pernapasan akan terjadi penurunan, dan kemudian dapat mengakibatkan seseorang menjadi lebih rentan terkena ISPA. Pada saat memasuki usia 22 - 24 tahun fungsi paru akan mencapai nilai masksimalnya, namun setelah itu akan menetap dan menurun dan setelah memasuki umur 30 tahun secara perlahan fungsi paru akan menurun (Rahmatullah 2009) ${ }^{[7]}$.

Usia 51 tahun bisa dikatakan telah memasuki masa lansia awal. Semakin lama usia bertambah kekuatan otot pernapasan pada saat menghirup oksigen terjadi penurunan, kemudian seiring bertambahnya umur 
semakin banyak pula alveoli yang rusak dan sistem imunitas tubuh menurun yang akhirnya rentan terkena ISPA (Nelson 2014) ${ }^{[8]}$.

Variabel kebiasaan merokok (tabel 3), menunjukkan bahwa nilai chi square sebesar 27,466 lebih besar dari 3,84 dan p-value 0,000 lebih kecil dari $\alpha$ $(0,05)$ sehingga dinyatakan mempengaruhi kejadian penyakit ISPA petani di Kecamatan Ijen.

Kebiasaan merokok berdampak buruk bagi fungsi dan juga struktur jaringan pada saluran pernapasan. Merokok memiliki hubungan yang erat terhadap risiko peningkatan gangguan saluran pernapasan. Asap rokok menyebabkan kemampuan bulu getar dalam menangkap benda asing menurun sehingga mengakibatkan debu dengan mudah masuk ke dalam paru - paru (Yusnabeti 2011) ${ }^{[9]}$.

Sekitar 4000 bahan kimia berbahaya yang terkandung apabila dihisap dalam satu batang rokok. Di dalam paru - paru zat toksin dari rokok tersebut akan terakumulasi yang kemudian akan mengakibatkan terhambatnya proses pertukaran $\mathrm{CO} 2$ dan $\mathrm{O} 2$ di dalam alveolus. Sehingga akan fungsi paru tersebut terjadi penurunan akibat dari berkurangnya jumlah alveolus yang berperan (Stämpfli 2009) ${ }^{[10]}$.

Sejalan dengan penelitian pada efek rokok terhadap fungsi paru pada pekerja yang terkena pajanan fumes dan debu, disimpulkan bahwa dikalangan perokok peluang terkena gangguan pernapasan lebih tinggi dan para perokok lebih banyak mengalami gangguan ventilator restrektif apabila dibandingkan dengan pekerja yang tidak merokok (Mhase dan Rendy 2002) ${ }^{[11]}$

\section{Kesimpulan}

Hasil dari peneltitian yang dilakukan didapatkan kesimpulan :

1. Kebiasaan merokok berpengaruh terhadap kejadian ISPA pada petani didaerah aliran sungai kecamatan Ijen

2. Umur memiliki pengaruh yang signifikan terhadap kejadian penyakit ISPA.

\section{Ucapan Terima kasih}

Terima kasih kepada para petani didaerah aliran sungai kecamatan Ijen Kabupaten Bondowoso.

\section{Referensi}

[1] Kementrian Kesehatan Republik Indonesia. 2013. Riset Kesehatan Dasar. Jakarta : Balitbang

[2,] Nelson, 2014. Ilmu Kesehatan Anak. Jakarta : EGC

[3] Syam, A. F. 2012. Dampak Hipoksia Bagi Kesehatan. Artikel. Harian Seputar Indonesia, Sumber Referensi Terpercaya [serial

online].http://staff.blog.ui.ac.id/ari.fahrial/files/2012/04/Dampak-
Hipoksi-bagi- Kesehatan.pdf. [15 Februari 2019]

[4] Mukono, H J. 2003. Pencemaran Udara dan Pengaruhnya Terhadap Gangguan Saluran Pernapasan. Surabaya:Airlangga University Press

[5] Pujiani, Tri R. 2017. Hubungan Penggunaan APD Masker, Kebiasaan Merokok dan Volume Kertas Bekas dengan ISPA Jurnal. Fakultas Kesehatan Masyarakat Universitas Semarang.

[6] Sholikhah, A.M \& Sudarmaji. 2015. Hubungan Karakteristik Pekerja dan Kadar Debu Total Dengan Keluhan Pernapasan Pada Pekerja Industri Kayu X di Kabupaten Lumajang. Jurnal Kesehatan Lingkungan

[7] Rahmatullah P. 2009. Pneumonitis Dan Penyakit Paru Lingkungan. Edisi 5. Jakarta: Pusat Penerbitan Ilmu Penyakit Dalam.

[9] Yusnabeti Ririn. 2011. PM10 dan Infeksi Saluran pernapasan Akut pada Pekerja Industri Mebel. Skripsi. Jakarta: Universitas Indonesia

[10] Stämpfli, M., \& P Anderson, G. 2009. How cigarette smoke skews immune responses to promote infection, lung disease and cancer. Nature Reviews Immunology Journal.

[11] Mhase, Viju T. Reddy, P S N. 2002. Effect of Smoking on Lung Function of Workers Exposed to Dust and Fumes.Journal: L.T.M Medical College. Mumbai, India. 